\title{
Electrochemical Studies of Stainless Steel Corrosion in Peroxide Solutions
}

\author{
Ajay K. Singh, ${ }^{a, *}$ Vipin Chaudhary ${ }^{b}$ and A. Sharma ${ }^{c}$ \\ ${ }^{a}$ Department of Paper Technology, IIT-Roorkee, Saharanpur campus, \\ Saharanpur-247001, India \\ ${ }^{b}$ Department of Physics, J.V.Jain College, Saharanpur-247001, India \\ ${ }^{c}$ Graphic Era University, Dehradun, India
}

Received 20 February 2012; accepted 30 April 2012

\begin{abstract}
Pollution control measures have resulted in replacement of chlorine by peroxide as bleaching chemical. Change of chemical affects corrosion aspects, the suitability of existing plant metallurgy and materials of construction of bleach plants. Accordingly long term immersion and electrochemical corrosion tests were conducted on stainless steel 304L, 316L, 2205 and 6\% Mo and mild steel in peroxide solutions of $\mathrm{pH} 10$. The materials were tested for uniform corrosion, pitting and crevice corrosion and attack around the weld area. Corrosion attack estimated from long term immersion tests is found in agreement, by and large, with that analyzed from electrochemical test. E-pH diagrams drawn for water-peroxide system have been used to understand the corrosivity of the peroxide media. An attempt has been made to suggest a suitable material of construction for handling the test media on the basis of degree of corrosion attack on them and their cost and the mechanical properties.
\end{abstract}

Keywords: corrosion, peroxide, electrochemical test, stainless steel, material selection.

\section{Introduction}

The paper industry is adopting non-chlorine bleach chemicals for reducing pollution. Among these, hydrogen peroxide $\left(\mathrm{H}_{2} \mathrm{O}_{2}\right)$ has been widely accepted as an environment friendly bleach chemical as a part of total chlorine free (TCF) bleaching. Generally, paper mill bleach plants handle chlorine and chlorine dioxide whose acidic liquor is highly corrosive. Consequently, many bleach plants have been constructed of titanium because of its high corrosion resistance. Mills which expect to use peroxide as a bleach chemical or which may alternate elemental chlorine free (ECF) and TCF bleaching may use the same titanium plant for handling peroxide liquor. It is, therefore, necessary to check suitability

\footnotetext{
* Corresponding author. E-mail: ajaycorr@rediffmail.com
} 
of titanium in handling peroxide liquor which is alkaline. One of the earlier reported studies [1] showed titanium (Ti) experiencing severe attack in peroxide solutions. Yau [2,3] evaluated $\mathrm{Ti}$ and zirconium $(\mathrm{Zr})$ for applications in the bleach plant. $\mathrm{Zr}$ was found to be suitable for alkaline $\mathrm{H}_{2} \mathrm{O}_{2}$ solutions while $\mathrm{Ti}$ experienced much higher degree of corrosion. A contemporary study [4] showed that Ti equipment was suitable for short trials but inadequate for extended use in peroxide $(P)$ stage media. Since then many studies [5-17] have been conducted on corrosion performance of $\mathrm{Ti}$ in alkaline peroxide solutions which showed enhanced corrosion with higher $\mathrm{pH}$, temperature, and hydrogen peroxide concentration. Corrosion rates were found in acceptable range $(\sim 5 \mathrm{mpy})$ at room temperature for $\mathrm{pH} \sim 10$ and $0.2 \mathrm{gpl} \mathrm{H}_{2} \mathrm{O}_{2}$ concentration, but increased to $320-$ 480 mpy on increase of $\mathrm{pH}$ to 12 and $\mathrm{H}_{2} \mathrm{O}_{2}$ to $\sim 1.2 \mathrm{gpl}$, and further to $543 \mathrm{mpy}$ if temperature was also high $\left(80{ }^{\circ} \mathrm{C}\right)$. For highly corrosive conditions, $\mathrm{Ca}^{2+}$ was found to be most effective inhibitor followed by $\mathrm{SiO}_{3}{ }^{2-}$ and $\mathrm{Mg}^{2+}$. Been $[11,12]$ observed that inhibition effect of calcium was temporary and Sodium phosphate also showed inhibition under certain conditions. Chelating agents e.g. Ethylene Diamine Tetra acetic Acid (EDTA) and Diamine Triethylene Penta acetic Acid (DTPA), which are added in peroxide media to thwart hydrogen peroxide decomposition caused by metal ions of iron, copper, nickel, etc., were observed to either increase corrosion or have no effect.

Next option, in the search of suitable materials for handling alkaline peroxide media, is to test stainless steels (SS) against corrosion as they are among the commonly used materials due to their wide and varied corrosion resistance alongside strength and fabrication properties. An early study by Bloom et al. [1] suggests 300 series stainless steel as suitable material for handling alkaline hydrogen peroxide. Bennett [18] found that addition of peroxide to chlorine dioxide bleach stage is expected to initiate crevice corrosion of SS-316L if $\mathrm{pH}<$ 6.0. In another study [19], SS-304 and 316 were found to be suitable for use, without the risk of localized corrosion, in peroxide media $(\mathrm{pH} \sim 10)$ without $\mathrm{Cl}^{-}$ ions. SS-316 resisted localized corrosion until $500 \mathrm{ppm} \mathrm{Cl}^{-}$level. The addition of chelants reduces the corrosivity of liquors to the extent that SS-316 can handle higher chloride contents of $\sim 1500$ ppm and SS-304 200 ppm without experiencing pitting in the peroxide bleach liquor. In yet another study [20], stainless steel was observed to experience transpassive corrosion in the presence of phosphonate salts, often used as stabilizers of hydrogen peroxide. Bauer et al. [21] observed attack on SS-304L and other alloy steels in the strong oxidizing environment of alkaline hydrogen peroxide section. Another study [22] showed SS-316L to be highly susceptible to pitting attack whereas titanium modified stainless steel showed marginal improvement.

Apart from titanium and stainless steels, zirconium also is considered a candidate material for handling peroxide liquor. It shows higher degree of corrosion resistance as compared to titanium and stainless steel [2,2,23] and unlike them does not require the presence of corrosion inhibitors and/or chelants for peroxide stabilization. But zirconium is expensive [2] and shows similar corrosion resistance as stainless steel 316L [23] in the environment prevailing in peroxide bleach media. 
Outokumpu, Finland [24] reports that $\mathrm{H}_{2} \mathrm{O}_{2}$ is harmless to stainless steels, even at fairly high concentrations and temperatures. Although it is very strong oxidant, the use of this compound as bleaching agent avoids introducing chlorides that breaks down the passive layer of the stainless steels under oxidizing conditions. Experience has shown that SS-316L is in most cases resistant enough in such bleaching environments provided that halides are only present in trace amounts. However, care should be taken to avoid external stress corrosion cracking under wet insulation for which duplex stainless steels should be more resistant in pulp and paper mill environments. In view of the above, it appears very important to test the suitability of stainless steels in alkaline peroxide environment with varying chloride content against uniform and localized corrosion. The present paper describes the tests performed on stainless steels (austenitic and duplex) and mild steel in peroxide liquors of varying peroxide and chloride concentrations which may be observed in bleach plant. For this purpose, immersion test and electrochemical test were performed. E-pH diagram was also constructed for $\mathrm{H}_{2} \mathrm{O}_{2}-\mathrm{H}_{2} \mathrm{O}$ system with a view to help in understanding the corrosion reactions taking place in the present case.

\section{Experimental details \\ Materials}

The test materials were shortlisted on the basis of their present and possible use in future bleach plants. Accordingly, austenitic stainless steel 304L (S30403), 316L (S31603), 6\% Mo (S31254), duplex stainless steel 2205 (S32205) and mild steel (ms) were selected for the test. Immersion test was performed on the corrosion coupons from plate samples of the respective steels. The stainless steel coupons were autogenously welded. Cylindrical samples from the rods of the above steels (except mild steel) were examined using electrochemical tests. The composition of the stainless steels, for plate and cylindrical samples, is shown in Table 1.

Table 1. Composition of test materials.

\begin{tabular}{|l|c|c|c|c|c|c|c|c|c|c|}
\hline \multicolumn{10}{|c|}{ Plate Samples } \\
\hline Alloy & $\mathrm{C}$ & $\mathrm{Cr}$ & $\mathrm{Ni}$ & $\mathrm{Mo}$ & $\mathrm{Cu}$ & $\mathrm{Mn}$ & $\mathrm{P}$ & $\mathrm{S}$ & $\mathrm{Si}$ & $\mathrm{N}$ \\
\hline mild steel & 0.18 & - & - & - & - & 1.66 & - & - & 0.04 & - \\
\hline 304L & 0.036 & 18.11 & 8.01 & 0.26 & 0.46 & 1.84 & 0.024 & 0.001 & 0.44 & 0.058 \\
\hline 316L & 0.019 & 17.43 & 11.26 & 2.03 & 0.40 & 1.11 & 0.027 & 0.002 & 0.5 & 0.048 \\
\hline 2205 & 0.022 & 22.13 & 5.55 & 3.16 & 0.21 & 1.47 & 0.02 & 0.001 & 0.35 & 0.188 \\
\hline 6\% Mo SS & 0.011 & 19.90 & 17.90 & 6.07 & 0.67 & 0.43 & 0.024 & 0.001 & 0.31 & 0.203 \\
\hline \multicolumn{10}{|c|}{ Cylindrial Samples } \\
\hline 304L & 0.02 & 18.10 & 11.52 & - & - & 1.92 & - & - & 0.59 & - \\
\hline 316L & 0.02 & 17.44 & 10.87 & 2.16 & 0.31 & 1.69 & 0.03 & 0.03 & 0.69 & 0.04 \\
\hline 2205 & 0.02 & 22.25 & 5.48 & 3.08 & - & 1.45 & 0.026 & 0.002 & 0.52 & 0.15 \\
\hline $6 \%$ Mo SS & 0.009 & 20.10 & 18.00 & 6.15 & 0.74 & 0.44 & 0.028 & 0.001 & 0.31 & 0.20 \\
\hline
\end{tabular}

All the stainless steel test samples were as received in the solution annealed condition as per ASTM spec A240. Before exposure, they were polished by emery paper of decreasing grain size with minimum of 600 grit, then degreased using acetone solution and weighed in the case of immersion test. 


\section{Solutions}

Samples were exposed in peroxide solutions having $\mathrm{pH}=10$ and varying $\mathrm{Cl}^{-}$and peroxide concentration. For preparing these solutions, $30 \% \mathrm{H}_{2} \mathrm{O}_{2}$ Analar grade in distilled water was used. This solution was mixed in distilled water in required amount so as to have 300 and $600 \mathrm{ppm} \mathrm{H}_{2} \mathrm{O}_{2}$ and their $\mathrm{pH}$ was adjusted to 10 using $\mathrm{NaOH}$. $\mathrm{NaCl}$ was added in the solutions so as to have desired level of $\mathrm{Cl}^{-}$ content. The composition of the solutions was checked for $\mathrm{H}_{2} \mathrm{O}_{2}, \mathrm{Cl}^{-}$and $\mathrm{pH}$ using standard techniques [25] and $\mathrm{pH}$ meter. Table 2 shows the composition of test solutions.

Table 2. Chemical composition of test solutions $(\mathrm{pH}=10)$.

\begin{tabular}{|l|c|c|c|c|c|c|}
\hline & Soln 1 & Soln 2 & Soln 3 & Soln 4 & Soln 5 & Soln 6 \\
\hline Peroxide (ppm) & 300 & 300 & 300 & 600 & 600 & 600 \\
\hline Chloride $(\mathrm{ppm})$ & 0 & 500 & 1000 & 0 & 500 & 1000 \\
\hline
\end{tabular}

\section{Tests}

The immersion test was performed for estimation of corrosion rate, in which weighed steel coupons were exposed for six months at room temperature. Each coupon, fitted with serrated washers for initiating crevice corrosion, configuration as per Fig. 2a of ASTM G78 [26], was immersed in the test solution (Table 2).

During the test, $\mathrm{H}_{2} \mathrm{O}_{2}, \mathrm{Cl}^{-}$and $\mathrm{pH}$ of the solutions were monitored and maintained once in a week. During this period, \% ranges within which the concentrations in solution decreased from the target values were: $7 \%-15 \%$ of $\mathrm{H}_{2} \mathrm{O}_{2}, 2.7 \%-5 \%$ of $\mathrm{Cl}^{-}$and $3.5-5 \%$ of $\mathrm{pH}$. After the exposure, the corroded coupons were cleaned according to ASTM G1-10 (27). The coupons were then weighed for estimating weight loss in order to determine corrosion rate, representing annualized areaaveraged thinning rate, using the following equation

\section{Corrosion Rate $(\mathrm{mpy})=\left(3.45 \times 10^{6} \times \mathrm{w}\right) /(\mathrm{D} \mathrm{A} \mathrm{T})$}

where $\mathrm{W}$ is the weight loss in grams, $\mathrm{D}$ is the density of metal in $\mathrm{gm} / \mathrm{cm}^{3}, \mathrm{~A}$ is the area in $\mathrm{cm}^{2}$ and $\mathrm{T}$ is the exposure time in hours.

The corroded and cleaned coupons were also viewed under the microscope for estimating pitting, crevice corrosion and weld related attack by measuring the maximum depth of attack on the open surface, under the serrated washer and near the weld area of the coupon, respectively [28].

The electrochemical tests, namely potential ' $E$ ' vs. time ' $t$ ', potentiodynamic and cyclic polarization (Fig.1) and potentiostatic (Fig.2) were conducted in these solutions. The corrosion measurement system included a potentiostat and a polarization cell having five necks meant for a working electrode, two counter electrodes, saturated calomel electrode (SCE) as reference electrode and for gas purging. Open circuit potential $(\mathrm{OCP})$, corrosion potential $\left(\mathrm{E}_{\mathrm{corr}}\right)$, critical pitting potential $\left(E_{c}\right)$, repassivation potential $\left(E_{p}\right)$ and margin of safety $\left(\mathrm{MOS}=\mathrm{E}_{\mathrm{c}}-\right.$ $\left.\mathrm{E}_{\text {corr }}\right)$ were evaluated from these tests. 


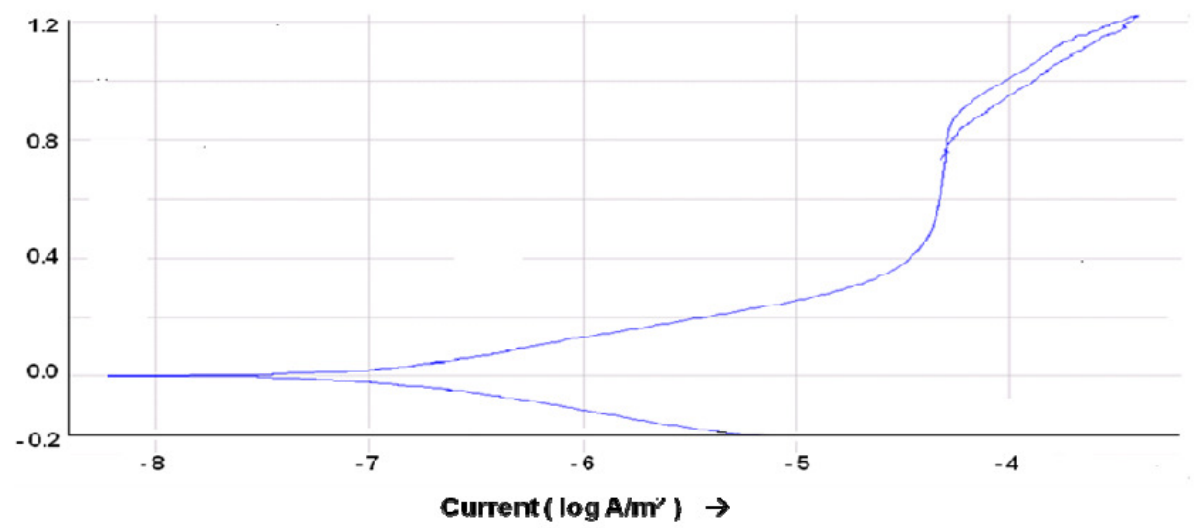

Figure 1. Cyclic polarization curve of 2205 in peroxide solution 6.

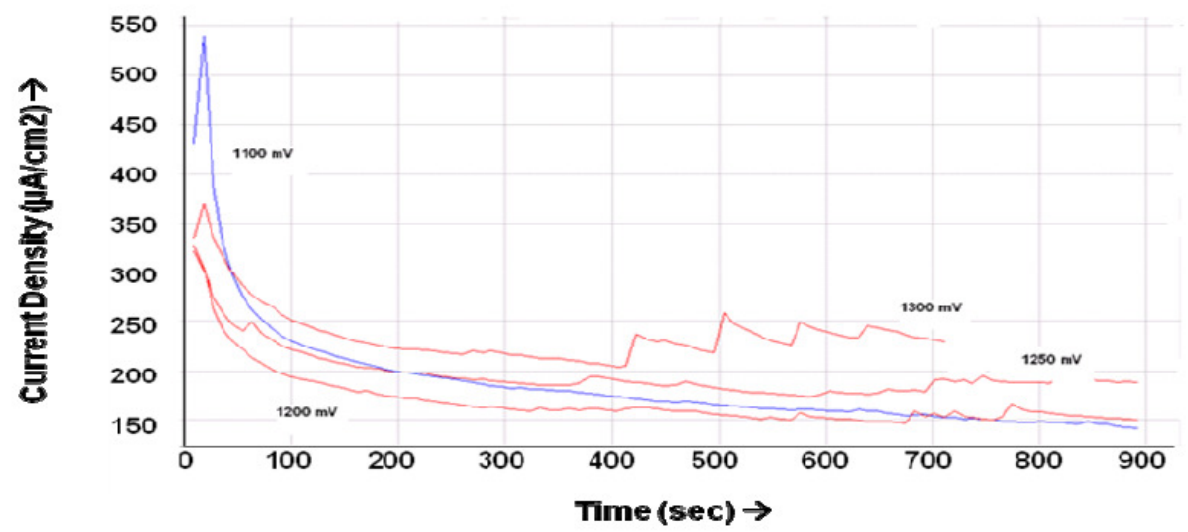

Figure 2. Potentiostatic curves for stainless steel 316L in solution 4.

\section{Results and discussion}

To understand various reactions, responsible for the corrosion of materials, information is required on the chemical species present in the solutions. For this purpose an E-pH diagram [29] was constructed for $\mathrm{H}_{2} \mathrm{O}_{2}-\mathrm{H}_{2} \mathrm{O}$ system (Fig.3) using the following reactions and their corresponding equations $(1-5)$ with the amount of $\mathrm{H}_{2} \mathrm{O}_{2}$ taken as 300 and 600 ppm, same as those in the test solutions.
1. $\mathrm{H}_{2} \mathrm{O}_{2} \leftrightarrow \mathrm{HO}_{2}^{-}+\mathrm{H}^{+}$
2. $2 \mathrm{H}_{2} \mathrm{O} \leftrightarrow \mathrm{H}_{2} \mathrm{O}_{2}+2 \mathrm{H}^{+}+2 \mathrm{e}^{-}$
3. $2 \mathrm{H}_{2} \mathrm{O} \leftrightarrow \mathrm{HO}_{2}^{-}+3 \mathrm{H}^{+}+2 \mathrm{e}^{-}$
4. $\mathrm{H}_{2} \mathrm{O}_{2} \leftrightarrow \mathrm{O}_{2}+2 \mathrm{H}^{+}+2 \mathrm{e}^{-}$
5. $\mathrm{HO}_{2}^{-} \leftrightarrow \mathrm{O}_{2}+\mathrm{H}^{+}+2 \mathrm{e}^{-}$

$\log \left[\mathrm{HO}_{2}^{-}\right] /\left[\mathrm{H}_{2} \mathrm{O}_{2}\right]=-11.63+\mathrm{pH}$

$\mathrm{E}_{\mathrm{H} 2 \mathrm{O} 2 / \mathrm{H} 2 \mathrm{O}}=1.776-0.0591 \mathrm{pH}+0.0295 \log \left[\mathrm{H}_{2} \mathrm{O}_{2}\right]$

$\mathrm{E}_{\mathrm{HO} 2-/ \mathrm{H} 2 \mathrm{O}}=2.119-0.0886 \mathrm{pH}+0.0295 \log \left[\mathrm{HO}_{2}{ }^{-}\right]$

$\mathrm{E}_{\mathrm{O} 2 / \mathrm{H} 2 \mathrm{O} 2}=0.682-0.0591 \mathrm{pH}+0.0295 \log \left[\mathrm{P}_{\mathrm{O} 2}\right] /\left[\mathrm{H}_{2} \mathrm{O}_{2}\right]$

$\mathrm{E}_{\mathrm{O} 2 / \mathrm{HO} 2-}=0.338-0.0295 \mathrm{pH}+0.0295 \log \left[\mathrm{P}_{\mathrm{O} 2}\right] /\left[\mathrm{HO}_{2}{ }^{-}\right]$ 


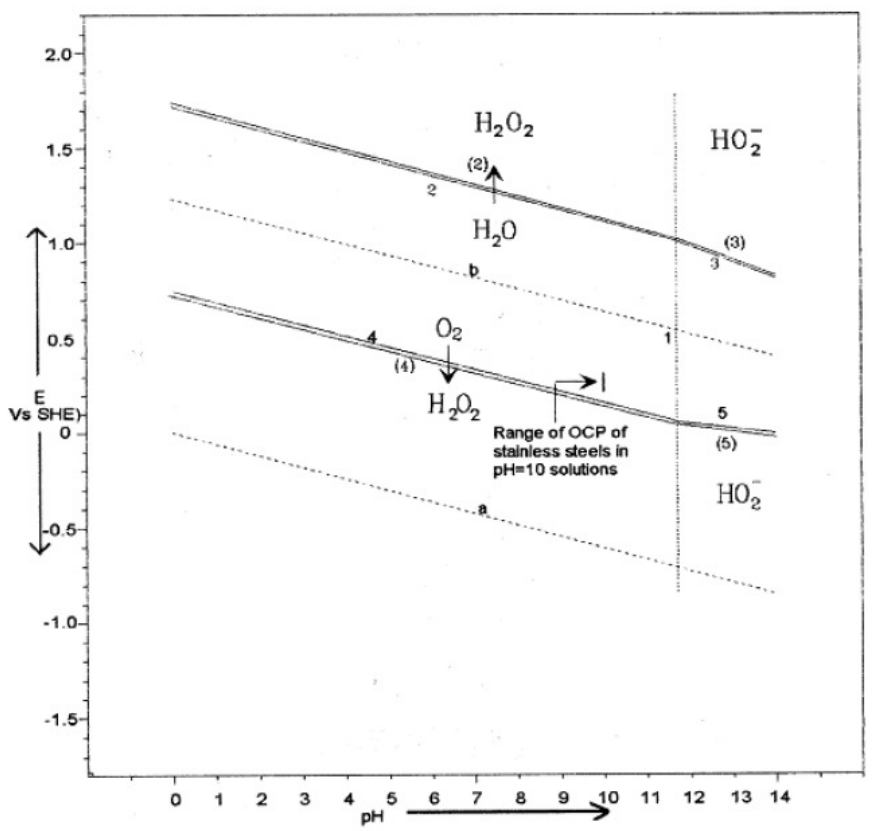

Figure 3. E-pH diagram for $\mathrm{H}_{2} \mathrm{O}_{2} / \mathrm{H}_{2} \mathrm{O}$ system at room temperature and 300 and 600 ppm peroxide levels.

Fig. 3 shows the range of potential within which OCP values of different stainless steels lie, when exposed in the present test solution. Because this range is lying near line 4 which shows $\mathrm{H}_{2} \mathrm{O}_{2} / \mathrm{O}_{2}$ equilibrium (reaction/Eqn. 4), i.e., $\mathrm{O}_{2}$ reducing to $\mathrm{H}_{2} \mathrm{O}_{2}$ and $\mathrm{H}_{2} \mathrm{O}_{2}$ oxidizing to $\mathrm{O}_{2}$, a solution having peroxide at this $\mathrm{pH}$ and potential value will have $\mathrm{H}_{2} \mathrm{O}_{2}$ and $\mathrm{O}_{2}$ as the chemicals in the solution and so will be responsible for the following reduction reactions

$$
\begin{gathered}
\mathrm{H}_{2} \mathrm{O}_{2}+2 \mathrm{H}^{+}+2 \mathrm{e}^{-} \rightarrow 2 \mathrm{H}_{2} \mathrm{O}-(2) \\
\mathrm{O}_{2}+4 \mathrm{H}^{+}+2 \mathrm{e}^{-} \rightarrow 2 \mathrm{H}_{2} \mathrm{O}-(6)
\end{gathered}
$$

Due to higher potential of $\mathrm{H}_{2} \mathrm{O}_{2}$ reduction (reaction 2), it dominates in influencing the corrosion of steels in peroxide solutions. $\mathrm{H}_{2} \mathrm{O}_{2}$ reduction will result in increase of $\mathrm{pH}$ of the solution as corrosion proceeds, as was observed while monitoring $\mathrm{pH}$ during immersion test.

Table 3. Corrosion rate of steels in peroxide solutions ( in mpy*).

\begin{tabular}{|l|c|c|c|c|c|c|}
\hline & Soln 1 & Soln 2 & Soln 3 & Soln 4 & Soln 5 & Soln 6 \\
\hline mild steel & 6.26 & 6.8 & 6.98 & 6.39 & 7.82 & 9.43 \\
\hline SS-304L & 1.18 & 1.18 & 1.21 & 1.23 & 1.27 & 1.49 \\
\hline SS-316L & 0.11 & 0.19 & 0.19 & 0.20 & 0.22 & 0.25 \\
\hline 2205 & 0.001 & 0.005 & 0.01 & 0.011 & 0.012 & 0.013 \\
\hline $6 \%$ Mo SS & 0.003 & 0.004 & 0.005 & 0.003 & 0.005 & 0.005 \\
\hline
\end{tabular}

Corrosion rates for different steels in various solutions are given in Table 3. One observes peroxide solution without $\mathrm{Cl}^{-}$to be least corrosive. Addition of $\mathrm{Cl}^{-}$and increased $\mathrm{H}_{2} \mathrm{O}_{2}$ concentration shows higher corrosion rates for respective materials. Extent of pitting, crevice corrosion and weld area attack on different 
steels in the test solutions (Table 4) are also found, generally, to increase with higher $\mathrm{H}_{2} \mathrm{O}_{2}$ and $\mathrm{Cl}^{-}$contents. Thus peroxide solution with no chloride and 300 ppm peroxide is least corrosive, while that with $1000 \mathrm{ppm}$ chloride and $600 \mathrm{ppm}$ peroxide shows highest degree of corrosivity. The increased corrosivity of the solutions with $\mathrm{H}_{2} \mathrm{O}_{2}$ may be assigned to $\mathrm{H}_{2} \mathrm{O}_{2} / \mathrm{H}_{2} \mathrm{O}$ reaction (Reaction 2). According to Nernst equation for this reaction (Eqn. 2) increase in concentration of $\mathrm{H}_{2} \mathrm{O}_{2}$ will shift $\mathrm{E}_{\mathrm{H} 2 \mathrm{O} 2 / \mathrm{H} 2 \mathrm{O}}$ to higher values. Consequently line 1, showing variation of $\mathrm{E}_{\mathrm{H} 2 \mathrm{O} / \mathrm{H} 2 \mathrm{O}}$ with $\log \mathrm{i}$, in Fig.4, will shift to more positive potentials (line 1'). This change will result in increasing OCP/Ecorr and corrosion rate of metal (A $\rightarrow$ A') (Fig.4). Enhanced corrosivity due to increased level of $\mathrm{Cl}^{-}$may be attributed to decrease in critical pitting potential $\left(\mathrm{E}_{\mathrm{c}}\right)$ of stainless steel on increase in $\mathrm{Cl}^{-}$content in solution. This in turn will increase corrosion rate and may enhance possibility of localized corrosion as well since now line 1 cuts anodic polarization curve of metal in transpassive region at A" (Fig.4). Thus corrosivity of the peroxide solutions is likely to increase with increased residual peroxide and chloride levels which may be observed because of filtrate recycling to control discharge of pollutants.

Table 4. Pitting, crevice corrosion and weld related attack* (depth in $\mu \mathrm{m}$ ).

\begin{tabular}{|c|c|c|c|c|c|c|c|}
\hline & & Soln 1 & Soln 2 & Soln 3 & Soln 4 & Soln 5 & Soln 6 \\
\hline \multirow[t]{3}{*}{ mild steel } & Pitting & - & - & - & - & - & 59 \\
\hline & $\begin{array}{l}\text { Crevice } \\
\text { Corrosion }\end{array}$ & 72 & 88 & 90 & 73 & 79 & 102 \\
\hline & $\begin{array}{l}\text { Weld Area } \\
\text { Attack }\end{array}$ & - & - & - & - & - & - \\
\hline \multirow[t]{3}{*}{ SS-304L } & Pitting & 40 & 36 & 45 & 50 & 71 & 85 \\
\hline & $\begin{array}{l}\text { Crevice } \\
\text { Corrosion }\end{array}$ & NMA & 35 & 40 & 41 & 52 & 53 \\
\hline & $\begin{array}{l}\text { Weld Area } \\
\text { Attack }\end{array}$ & NMA & NMA & NMA & 63 & 78 & 115 \\
\hline \multirow[t]{3}{*}{ SS-316L } & Pitting & 58 & 81 & 84 & 60 & 75 & 109 \\
\hline & $\begin{array}{l}\text { Crevice } \\
\text { Corrosion }\end{array}$ & 47 & 67 & 71 & 41 & 85 & 105 \\
\hline & $\begin{array}{l}\text { Weld Area } \\
\text { Attack }\end{array}$ & NMA & 40 & 43 & 35 & 62 & 78 \\
\hline \multirow[t]{3}{*}{2205} & Pitting & 39 & 36 & 48 & 55 & 57 & 64 \\
\hline & $\begin{array}{l}\text { Crevice } \\
\text { Corrosion }\end{array}$ & NMA & NMA & 40 & NMA & 44 & 46 \\
\hline & $\begin{array}{l}\text { Weld Area } \\
\text { Attack }\end{array}$ & NMA & NMA & 41 & NMA & 41 & 44 \\
\hline \multirow[t]{3}{*}{$6 \%$ Mo SS } & Pitting & 41 & 35 & 41 & 40 & 51 & 52 \\
\hline & $\begin{array}{l}\text { Crevice } \\
\text { Corrosion }\end{array}$ & NMA & NMA & NMA & NMA & NMA & NMA \\
\hline & $\begin{array}{l}\text { Weld Area } \\
\text { Attack }\end{array}$ & NMA & NMA & NMA & NMA & NMA & NMA \\
\hline
\end{tabular}

NMA - No measurable attack; *measured as maximum depth of attack, over open area, under the crevices and at welded joint, respectively.

The ranking of corrosion rates, according to Table 3 , is

$$
\text { mild steel }>304 \mathrm{~L}>316 \mathrm{~L}>2205 \sim 6 \% \text { Mo SS }
$$

though in majority of the cases, $6 \%$ Mo SS shows slightly better performance. The trend is as per the chemical composition of the test materials. According to Table 4, ms is observed to experience only crevice corrosion, while pitting is 
experienced in one case only. An interesting observation is that SS 304L is found to perform better than SS $316 \mathrm{~L}$ in terms of pitting and crevice corrosion. Normally, it is expected that 316L will show better resistance than 304L. Such a behavior has been observed earlier also [30] and though some explanation has been suggested, the authors feel that a detailed study is required in this regard. Localized corrosion on duplex stainless steel 2205 is observed to be lesser while $6 \%$ Mo SS shows best resistance (Table 4). Attack on weld area is found maximum on SS 304L, which is followed by SS 316L and duplex stainless steel 2205, while 6\% Mo SS does not show any crevice corrosion and weld area attack. Thus by and large, different materials may be graded in terms of their resistance against corrosion in the following manner : 6\% Mo SS > 2205 > 316L $>$ 304L > mild steel

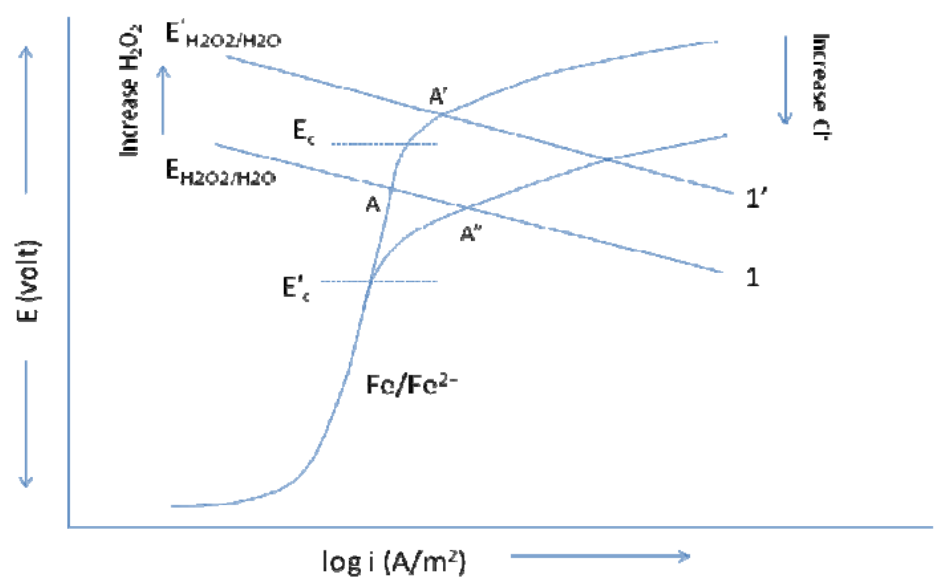

Figure 4. Effect of $\mathrm{H}_{2} \mathrm{O}_{2}$ and $\mathrm{Cl}^{-}$on corrosion of stainless steel.

Table 5: Electrochemical corrosion parameters.

\begin{tabular}{|c|c|c|c|c|c|c|c|}
\hline & & Soln 1 & Soln 2 & Soln 3 & Soln 4 & Soln 5 & Soln 6 \\
\hline SS-304L & OCP & -23.95 & -11.97 & 16.44 & 43.37 & 55.6 & - \\
\hline \multirow{6}{*}{ SS-316L } & $\mathrm{OCP}$ & 43.67 & 28.2 & -17.74 & 48.42 & 48.3 & 46.2 \\
\hline & Ecorr & -29.7 & -18.32 & -27.59 & 3.16 & & 11.4 \\
\hline & $(\mathrm{Ec})_{\mathrm{pot}}$ & 1076 & 373.7 & 274.7 & 1151 & & 288.8 \\
\hline & (Ec)potstatic & & & & 1275 & & \\
\hline & $\mathrm{Ep}$ & & & & & & \\
\hline & MOS & 1105.7 & 390.02 & 302.3 & 1147.8 & & 277.4 \\
\hline \multirow[t]{7}{*}{2205} & OCP & 45.38 & 15.48 & 26.77 & 28.22 & 65.1 & 62.8 \\
\hline & Ecorr & & -35.2 & $47.8 / 16^{*}$ & & & $36.2 / 0^{*}$ \\
\hline & $(\mathrm{Ec})_{\mathrm{pot}}$ & & 966.6 & 955 & & & 1027 \\
\hline & $(\mathrm{Ec})_{\text {cyclic }}$ & & & 946.5 & & & 877.9 \\
\hline & (Ec)potstatic & & & 1125 & & & $>1100$ \\
\hline & $\mathrm{Ep}$ & & & 938.2 & & & 766 \\
\hline & MOS & & 1001.8 & $907 / 930.5$ & & & $990.8 / 877.9$ \\
\hline \multirow[t]{3}{*}{$6 \%$ Mo SS } & $\mathrm{OCP}$ & 33.29 & -1.29 & 42.06 & 45.59 & 76.5 & 67.8 \\
\hline & Ecorr & -28.51 & & & & & \\
\hline & $(\mathrm{Ec})_{\mathrm{pot}}$ & 1150 & & & & & \\
\hline
\end{tabular}

All parameters are in 'millivolt', measured w.r.t. SCE; * cyclic measurement, MOS - margin of safety, $\left(\mathrm{E}_{\mathrm{c}}\right)_{\text {pot }}$, $\left(\mathrm{E}_{\mathrm{c}}\right)_{\text {cyclic }}$, $\left(\mathrm{E}_{\mathrm{c}}\right)_{\text {potstatic }}-\mathrm{E}_{\mathrm{c}}$ obtained from potentiodynamic, cyclic polarization and potentiostatic measurements, respectively. 
Table 5 shows the results derived from electrochemical polarization tests. Thus OCP values are lying in the range -23.95 to $76.5 \mathrm{mV}$ with respect to SCE $(218.05$ to $318.5 \mathrm{mV}$ w.r. to $\mathrm{SHE}$ as shown in E-pH diagram). Generally $\mathrm{E}_{\text {corr }}<\mathrm{OCP}$ because for OCP measurement, one has to run the experiment for longer duration, so potential rises with built up of corrosion product layer.

For SS 316L, $\mathrm{E}_{\mathrm{c}}(1076 \rightarrow 373.7 \rightarrow 274.7 \mathrm{mV})$ and $\operatorname{MOS}(1105-390.2-302.3$ $\mathrm{mV}$ ) fall very rapidly with introduction of $\mathrm{Cl}^{-}$. Accordingly, cyclic polarization curves were not recorded in $\mathrm{Cl}^{-}$containing solutions since $\mathrm{E}_{\mathrm{p}}$ would have turned out to be lower than $\mathrm{E}_{\text {corr }}$. The above behavior indicates the vulnerability of SS $316 \mathrm{~L}$ to attack by pitting and crevice corrosion in alkaline peroxide solutions having $\mathrm{Cl}^{-}$.

For duplex stainless steel 2205, $\mathrm{E}_{\mathrm{c}}, \mathrm{E}_{\mathrm{p}}$ and MOS are observed to be quite high, indicating much better resistance of this steel even in case of peroxides having $1000 \mathrm{ppm} \mathrm{Cl}^{-}$. For increased peroxide level, there is a slight reduction in the resistance against localized corrosion. Higher amount of $\mathrm{Cr}, \mathrm{Mo}$ and $\mathrm{N}$ in duplex stainless steel 2205 may be responsible for its better performance than SS 316L. $6 \%$ Mo SS is expected to perform even better than 2205, evident from higher value of Ec and MOS in non-chloride peroxide solution, since the former steel has higher amount of Mo and $\mathrm{N}$ although a little lesser amount of $\mathrm{Cr}$ as compared to 2205. These observations can be attributed to their Pitting Resistance Equivalent Number (PRE No.). PRE No. of stainless steels shows their resistance against localized corrosion in chloride containing oxidizing media [31] and is calculated by following equation:

$$
\text { PRE No. }=\% \mathrm{Cr}+3.3 \% \mathrm{Mo}+30 \% \mathrm{~N}
$$

PRE no. for 6\% Mo SS is 46, while that of 2205 is 37.6, indicating the former stainless steel to perform better against localized corrosion than the latter one. Localized corrosion in stainless steels is a consequence of breaking of passivation layer which is accelerated by the presence of chloride ions in the media. Improvement in resistance against localized corrosion, in $\mathrm{Cl}^{-}$containing media, can be observed if corrosion product layer has chromium and molybdenum oxides and so acts as passive layer. Formation of passive layer in stainless steel due to presence of $\mathrm{Cr}$, Mo and $\mathrm{N}$ has been observed earlier [19] also and its protective properties can be understood as follows. Presence of $\mathrm{Cr}$ helps in formation $\mathrm{Cr}(\mathrm{OH})_{3} / \mathrm{Cr}_{2} \mathrm{O}_{3}$ while $\mathrm{Mo}$ forms $\mathrm{MoO}_{2}$, which are protective type hence oxide layer produced is passive [29]. Nitrogen in stainless steel is observed as negatively charged ion on the metal surface under a passive film [32]. Presence of nitrogen ion therefore suppresses the adsorption of $\mathrm{Cl}^{-}$ions on the passivating film or slowing down of their access to it. This process enhances stability of the passive film [33].

A comparison of overall material performance against corrosion indicates $6 \%$ Mo SS as the best material. However, this steel is costlier than 2205. Even the performance of the 2205 against corrosion attack falls in acceptable category. Better cost/strength ratio of 2205 makes it all the more suitable for handling peroxide media with/without $\mathrm{Cl}^{-}$content. 


\section{Conclusion}

In the present work, electrochemical polarization test and immersion test were performed on various stainless steels in $\mathrm{Cl}^{-}$containing alkaline peroxide solutions at room temperature. To understand various reactions responsible for corrosion of stainless steels in peroxide solutions, E-pH diagrams of peroxide-water system were also drawn. It is concluded that (i) alkaline peroxide solutions with/without $\mathrm{Cl}^{-}$are corrosive to tested stainless steels to varying extent and their corrosivity increases with increase in $\mathrm{H}_{2} \mathrm{O}_{2}$ and $\mathrm{Cl}^{-}$content; (ii) though $6 \% \mathrm{Mo}$ SS shows maximum resistance against corrosion attack, optimum material for handling these media is suggested to be 2205; (iii) in the event of mills going for filtrate recycling, test should be made to check the corrosion resistance of the tested steels which is likely to deteriorate in view of the enhanced levels of $\mathrm{Cl}^{-}$ and oxidant.

\section{References}

1. R. Bloom, Jr., L.E. Weeks and C.W. Rayleigh, Corrosion 16 (1960) 164t.

2. T. Yau, TAPPI 1990 Engineering Conference, TAPPI PRESS, Atlanta, p1.

3. T. Yau, Material Performance 32(6) (1993) 65.

4. $\quad$ S.J. Clarke and D.L. Singbeil, Pulp \& Paper Canada 95 (1994) T417.

5. J.A. Macdiarmid and D.L. Reichert, 1992 International Symposium on Corrosion in Pulp \& Paper Industry, Atlanta, p 99.

6. W.E. Wyllie II, B.E. Brown and D.J. Duquette, NACE 1994: Corrosion Conference, NACE, Houston, p 21.

7. O.A. Varjonen and T.J. Hakkarainen, Tappi J. 78 (1995) 161.

8. W.E. Wyllie II, B.E. Brown and D.J. Duquette, Tappi J. 78 (1995) 151.

9. $\quad$ R.W. Schultz and M. Xiao, Tappi J. 78 (1995) 79.

10. D.L. Reichert, Paper No. 467, NACE Corrosion Conference (NACE International, Texas) 1996, 467/1-467/8.

11. J. Been, Titanium Corrosion in Alkaline Hydrogen Peroxide Envronments: Ph.D. Thesis (University of British Coulmbia, Canada) 1998.

12. J. Been and D. Tromans, Pulp \& Paper Canada 100 (1999) 50.

13. ASM Metal Handbook, Vol. 13, ASM International, Metals Park, 1987.

14. J. Rämö, Hydrogen Peroxide-Metals-Chelating Agents; Interactions and Analytical Techniques: Ph.D. Thesis (VTT, Helsinki University of Technology and University of Oulu, Finland) 2002.

15. J. Rämö, K. Saarinen and M. Sillanpää, Werkstoffe und Korrosion 53 (2002) 898.

16. E.R. Ruiz and C.M. Mendez, Titanium: Corrosion in Alkaline Hydrogen Peroxide Bleaching Environments, $2^{\text {nd }}$ Mercosur Congress on Chem. Engg. (Rio de Janiero) 2005, p 1-10.

17. L. Xei, X. Wang and J. Li, Key Engg. Material 330-332 (2007) 1285.

18. D.C. Bennett, Corrosion 40 (1984) 1.

19. R. Singh and A.K. Singh, Tappi J. 78 (1995) 111.

20. N.J. Laycock, R.C. Newman and J. Stewart, Corros Sci. 37 (1995) 1637. 
21. A.D. Bauer and M. Lundberg, Anti Corrosion Methods \& Materials 44 (1997) 161.

22. K.S.K. Danadurai and S. Rajeswari, Anti-Corrosion Methods and Materials 46 (1999) 14.

23. Zirconium in Hydrogen peroxide applications, Technical Data Sheet 2003 (ATI Wah Chang Allegheny Technologies), p 1-5.

24. Outokumpu, Web site 2005.

25. A.I. Vogel, Quantitative Inorganic Analysis, London, Longman, Green \& Co. p 296 (1964).

26. ASTM G78, Vol.03.02, Standard Guide for Crevice Corrosion Testing of Iron base and Nickel base Stainless alloys in Sea water and other chloride containing aqueous Environments (1991).

27. ASTM G1-10, Vol.03.02, Preparing, cleaning and evaluating corrosion test specimens, (1991).

28. A.H. Tuthill and D.E. Bardsley, Tappi Engg. Conf. Seattle 1990.

29. M. Pourbaix, Atlas of Electrochemical Equilibria in Aqueous Solutions, Houston, NACE: p 256 (1974).

30. A. Pehkonen, T. Salo, J. Aromaa and O. Forsen, Pulp \& Paper Canada 101 (2000) T104.

31. A. Garner, Avesta Stainless Steels for Chemical Pulp Bleach Plants, Information 9063:2, p 3, 14.

32. S.Yu. Mushnikova, M.V. Kostina, Ch.A. Andreev and L. Zhekova, Ts. Russian Metallurgy (Metally), 1 (2009) 30.

33. H.J. Grabke, Iron Steel Inst. Jap. Intern. 36 (1996) 777. 